\title{
DEVELOPMENT STRATEGY MANGROVE ECOTOURISM BASED ON LOCAL WISDOM
}

\author{
Syafri Harto, ${ }^{1}$ Rd. Siti Sofro Sidiq ${ }^{2}$ and Okta Karneli ${ }^{3}$ \\ ${ }^{1}$ Department of International Relations, Faculty of Social and Political Sciences, Riau University. \\ ${ }^{2}$ Department of Sociology, Faculty of Social and Political Sciences, Riau University \\ ${ }^{3}$ Department of Business Administration, Faculty of Social and Political Sciences, Riau University \\ E-mail: 'syafriharto@lecturer.unri.ac.id; ${ }^{2}$ sitisofrosidiq@lecturer.unri.ac.id; ${ }^{3}$ okta.karneli@lecturer.unri.ac.id
}

\begin{abstract}
Mangrove Bandar Mangrove mangrove ecotourism in the urban area of Dumai is an attraction between local and international tourists. The uniqueness of Bandar Bakau mangrove ecotourism is the school of nature, the potential for flora and fauna and its mangrove forests. Ecotourism Bandar Bakau is still relatively new, the division occurred in 1999 by community leaders and managed by non-governmental organizations and local communities. Mangrove ecotourism has 24 types of species and not all of their potential can be used to increase ecotourism because of the ability of people who do not understand, the high expectations of mangrove township communities for mangrove ecotourism make ecotourism management difficult to control professionally, so awareness is needed to build an agreement in building strategies local wisdom-based ecotourism development, therefore a mangrove ecotourism development strategy based on local wisdom is needed in Bandar Bakau. This study used a qualitative approach with descriptive methods and the data were analyzed using SWOT. The technique of determining the informants was purposive sampling with observation and in-depth interviews. The research results that have been analyzed illustrate that an alternative strategy for developing mangrove ecotourism based on local wisdom yields 4 important points, first to develop mangrove conservation and rehabilitation as a form of new tourism potential in mangrove ecotourism in Bandar Bakau, second to increase participation and empowerment based on local wisdom of the local community, third formulate regulations and policies to preserve mangroves based on local wisdom of the Malay community,
\end{abstract}

Keywords: Ecotourism; Mangrove Bandar Bakau; Local Wisdom

\section{STRATEGI PENGEMBANGAN EKOWISATA MANGROVE BERBASIS KEARIFAN LOKAL}

\begin{abstract}
ABSTRAK. Ekowisata mangrove bandar bakau yang berada di kawasan perkotaan Dumai menjadi daya tarik tersendiri bagi wisatawan lokal maupun international, keunikan dari ekowisata Bandar bakau ialah sekolah alam, potensi flora dan fauna serta hutan mangrovenya. Ekowisata Bandar bakau masih tergolong baru, pemekaran terjadi pada tahun 1999 oleh tokoh masyarakat dan di kelola oleh lembaga swadaya masyarakat dan masyarakat sekitar. Ekowisata mangrove memiliki 24 jenis spesies dan potensi yang dimiliki tidak semua bisa digunakan untuk peningkatan ekowisata karena kemampuan masyarakat yang belum mengerti, Tingginya harapan masyarakat bandar bakau terhadap ekowisata mangrove menyebabkan pengelolaan ekowisata sulit di kontrol secara profesional, sehingga dibutuhkan kesadaran kolektif untuk membangun kesepatakan dalam merancang strategi pengembangan ekowisata berbasis kearifan lokal, oleh karena itu dibutuhkan strategi pengembangan ekowisata mangrove berbasis kearifan lokal di Bandar bakau. Penelitian ini menggunakan pendekatan kualitatif dengan metode deskripitif serta data selanjutnya dianalisis dengan SWOT. Teknik penentuan informan dilakukan secara purposive sampling dengan observasi dan wawancara mendalam. Hasil penelitian yang telah di analisis menggambarkan bahwa alternative strategi pengembangan ekowisata mangrove berbasis kearifan lokal menghasilan 6point penting, pertama mengembangkan konservasi dan rehabilitasi mangrove sebagai bentuk potensi wisata baru di ekowisata mangrove Bandar bakau, kedua peningkatan partisipasi dan pemberdayaan berbasis kearifan lokal masyarakat sekitar, ketiga merumuskan peraturan dan kebijakan untuk menjaga kelestarian mangrove berbasis kearifan lokal masyarakat melayu, kempat penguatan konsep ekowisata di Bandar bakau yang bertujuan meningkatkan nilai ekonomi dan nilai keberlanjutan lingkungan, kelima peningkatan sumber daya manusia pengelola ekowisata dan terakhir memanfaatkan platform media sosial dan internet sebagai promosi ekowisata.
\end{abstract}

Kata kunci: Ekowisata; Mangrove Bandar Bakau; Kearifan Lokal.

\section{INTRODUCTION}

The potential of mangroves in the coastal areas of Indonesia reaches 2.5 ha (Rahadian,2019) mangrove forests are a biological natural resource that has potential and benefits for humans. Mangrove forest ecosystems have physical, economic, sociocultural and ecological functions, in terms of ecological functions as detritus income, spawning grounds, nursery grounds and feeding grounds for certain marine biota while from their physical function as a damper of sea waves, storm winds, and coastal protection. and retaining mud, the economic function has potential as a place for recreation and livelihoods for the community, while from a sociocultural perspective as a conservation area for marine culture development, education and research.

The development in the tourism sector gave birth to the right concept of tourism development, this 
concept is active in maintaining the sustainability of nature and culture in a sustainable manner so that in its aspect it is referred to as sustainable tourism. These aspects consist of economic, environmental and sociocultural aspects. This sustainable tourism development is known as ecotourism which supports ecological preservation and provides economically feasible and ethically and socially just benefits to the community (Edi, Okik Hendriyanto, \& Nur, 2009; Efendi, 2014).

One approach to tourism development that seeks to ensure that tourism can be carried out in coastal areas is the concept of ecotourism. ecotourism according to(Ghazali et al., 2014) is an area that offers authenticity both in terms of socioculture, customs, daily life, traditional architecture, village spatial structure which is presented in a form of integration of tourism components, including tourist attractions, accommodation and supporting (Sawitri, Bismark, \& Karlina, 2013). Accessibility is also very important in the development of tourism areas that determine whether it is easy or difficult for tourists to reach the desired tourist destinations. This component affects the cost, smoothness and comfort of a tourist who will take an attraction(Fitriana et al., 2016) (Fitriana et al., 2016)

As time goes by, the potential for mangroves is not only about the environment but has potential in the field of tourism, mangrove ecotourism is a renewal from old tourism to new tourism, according to Mastika (2018) ecotourism is a logical part of sustainable development, requires approaches from various disciplines, physical planning and human resource management, this is in line with research Wahyuni (2015) ecotourism is the government's effort to present the concept of tourism without neglecting the environment, ecotourism is the direction of developing fishermen's settlements in coastal areas both in terms of environmental aspects, socio-cultural values, spatial and integrated economic activities in the ecotourism area.

Coastal areas will become an important priority when potential management such as mangrove ecotourism is managed professionally, mangroves are the main ecosystem to support life in coastal areas and have a characteristic feature, namely muddy sand Dahuri.R (2003). Mangrove ecotourism according to Edy Saputra \& Setiawan (2014) has tourism potential and attractions such as learning activities, water tourism, beaches and local culture, all of which aim at economic development in coastal areas so that the standard of living of the surrounding community can increase.

The first definition of ecotourism was introduced by the organization The Ecotourism Society as follows: Ecotourism is a form of travel to natural areas carried out with the aim of conserving the environment and preserving the lives and welfare of local residents. Originally ecotourism was carried out by nature-loving tourists who wanted the tourist destination to remain intact and sustainable, in addition to maintaining the culture and welfare of the people.(Ghazali et al., 2014)

Ecotourism has direct and indirect contributions to research and conservation activities, mangrove ecotourism has several activities that can provide adaptation for humans to nature which is called the potential for mangrove ecotourism, according to Wardhani (2011) first is mangrove educational tour and tracking, second, bird watching, third, fishing, fourth, mangrove tree plantation or adoption, last is canoeing and boating. These are all potentials that can be developed in mangrove areas.

Riau Province is an area surrounded by coastal areas, especially Dumai City with the potential for mangrove forests in forest areas Mangrove Bandar bakau Pangkal Sesai sub-district, Dumai Barat subdistrict, is a flora habitat conservation area that is protected by a Regional Regulation. The mangrove forest has 24 protected mangrove species, this mangrove ecotourism is a tourist attraction for academics, education, local and international tourists to come see protected mangrove diversity.

According to Susanto (2016) Bandar Bakau is in the middle of the city center, port and settlement activities are still running so that it becomes a potential that must be developed, the community does not really understand the concept of ecotourism for the development of this area. This is in line with the results of observations made by research by mangrove conservation organizations area Bandar bakau Mangrove This management has not fully utilized the existing potential, there is a lack of an information center for tourists, access to lighting and the availability of rest areas for tourists that do not exist at all.

Local society Mangrove Bandar bakau having local wisdom such as cultural norms in certain traditional rituals, every guest arrival must carry out a traditional ceremony and have rules in protecting the natural surroundings. Local wisdom is a human way of thinking that has been rooted in the culture of a group for a long time, local wisdom in terms of tourism and anthropology is the relationship between humans, the environment and culture which is oriented to the results of dialectical relations. The orientation of the results of this human dialectical relationship creates a tradition that is influenced by the daily conditions of society and social institutions based on communitybased local culture (Zamzami, 2016).

Public Bandar bakau have a view that forests and sea have mutual influencing relationships, ecotourism management based on local wisdom involves the community as a determining factor for the success of ecotourism towards improving 
the economy and welfare for the mangrove bandau community, this is in line according to Kurniasari \& Reswati (2011) that behavior and the environment are two mutually defining and inseparable things. What a person does on land will affect what will happen at sea, and vice versa. Their knowledge of the relationship between sea and nature raises the perception that behavior in accordance with accepted norms must always be done so that the ecosystem is always stable and can be used sustainably. This belief is also what makes ecotourism management the main source of livelihood in Bandar Bakau, containing unique values and norms.

Local society Mangrove Bandar bakau The city of Dumai is dominated by the Malay tribe, the local wisdom of the Riau Malay tribe has a philosophy of protecting the environment, traditional Malay people and their surroundings. Bandar bakau Mangrove essentially as fishermen and farmers. Thamrin (2013)The Malay community has a proposition of local wisdom in maintaining the environment, the local wisdom value system of the Malay people in preserving it is always submissive and obedient to the teachings of religion and ancestors, the two values of local wisdom of the Malay people are individual manifestations of the Malay community that emerge from their traditions, the three values it is relative in accordance with the society in which it is and finally the local wisdom of the Malay community respects the value of any external culture.

The high expectations of mangrove port communities for mangrove ecotourism make ecotourism management difficult to control professionally, so that collective awareness is needed to build an agreement in designing ecotourism development strategies based on local wisdom, one of the ways that people do to manage coastal and marine areas is to define this area as a conservation area with customary leaders regulations and village regulations. According to Hermawan \& Setiawan (2018) To maintain the sustainability of mangrove ecotourism requires the attention of all relevant stakeholders, how to identify the potential both internally and externally and divide each area into protected forest and strengthened by existing regulations, this will facilitate the formulation of strategies for ecotourism development.

The development of ecotourism based on local wisdom is in line with the three principles of sustainable tourism development developed by the World Tourism Organization (WTO), namely ecological sustainability, socio-cultural sustainability, and economic sustainability, both for present and future generations. (Adyla \& Nurlaela, 2018) so the need for ecotourism development based on local wisdom in Dumai City to create sustainable ecotourism, to improve the economic welfare of local communities, and also to maintain, maintain and preserve the Malay cultural heritage which is a special attraction for tourists.

Emphasizing that local wisdom can help people overcome problems through the potential that exists in the community and can be developed in accordance with the situation, through this potential it is hoped that the community can develop, the economy increases, the community is prosperous and the poverty in the community is reduced Vuspitasari $\&$ Ewid (2020).

Therefore this research is intended to optimize mangrove resources and development strategies based on local wisdom mangrove town Dumai city, Riau Province for conservation efforts and recreational activities carried out in an appropriate and integrated manner.

\section{METHOD}

Research carried out on Ecotourism Bandar bakau Mangrove Pangkalan Sesai sub-district, West Dumai District, Dumai City. This research uses a qualitative approach with descriptive methods. Descriptive research was chosen to make it easier to get overall data. Descriptive research aims to explore problems in society with the relationships, activities, attitudes, views and processes in each of Nazir's (2003) phenomena.

The selection of informants using purposive sampling technique and this research through observation, interviews and descriptive studies to describe the behavior of each use of data analyzed by SWOT. According to Rangkuti (2005), the SWOT analysis is the result of research that will help in finding alternatives to each problem, therefore the researcher took the decision to use a SWOT analysis to see how the mangrove ecotourism development strategy in Dumai City.

\section{RESULTS AND DISCUSSION}

Mangrove mangrove ecotourism is located in the city of Dumai, a city close to the coast, the city of

Dumai is the largest city, the city has 7 subdistricts and originates from a coastal hamlet. Ecotourism Bandar mangroves have an area of nearly 20 ha, Bandar mangrove is directly opposite the Rupat strait, this has its own potential because it has views of the sea and ships in traffic. Mangrove Bandar bakau has 16 species categorized as true mangroves.

Mangrove bandar ecotourism has been championed since 1999, management Mangrove Bandar bakau handed over to marine nature lovers and the surrounding community who have their own local wisdom, marine nature lovers is a nongovernmental organization that is concerned about marine nature, especially mangrove forests, the Dumai City government through related agencies also helps in development, the role of stakeholders 
such as Pertamina through Corporate social responsibility providing assistance to maintain and develop mangrove ecotourism areas.

In the development strategy for ecotourism based on local wisdom, it requires some identification as a reference basis so that this development becomes right on target in the future, the results of research based on SWOT analysis are divided into 3, First, the identification of the potential for mangrove ecotourism in Bandar mangrove, both internal factor strategies and external factor strategies for developing Bandar mangrove ecotourism.

\section{Identification of Mangrove Ecotourism Potential Bandar Bakau Mangrove Dumai}

Tourism potential is defined as the ability, strength and resources that can be utilized for many audiences, according to Sari, et. all (2015) everything that is in a tourist destination and is an attraction for people to come and come time and time again. 4 components that must be owned by a tourist attraction, are attraction, accessibility, amenities and ancillary (Klein et al, 1995).

\section{Attraction Ecotourism Bandar Bakau Mangrove Dumai}

Bandar mangrove ecotourism conservation area has several untapped potential, the results of the study found that the natural potential of Bandar mangrove is divided into several types.

Table 1. Potential Flora Ecotourism Bandar Bakau Mangrove

\begin{tabular}{cl}
\hline No. & Mangrove Type \\
\hline 1 & Rhizophora apiculata \\
2 & Avicennia alba \\
3 & Avicennia marina \\
4 & Rhizophora mucronata \\
5 & Bruguiena gymnorrhiza \\
6 & Lumniteraa littorea \\
7 & Lumniteraa racemosa \\
8 & Ceriops tagal \\
9 & Sonneratia alba \\
10 & Nypafruitcans \\
\hline
\end{tabular}

Source: 2020 Research Results
Based on the results of observations of the potential for ecotourism Mangrove Bandar Bakau found several types of mangroves that do not exist in other ecotourism places, this is an attraction for researchers to continue to come to Bandar mangrove ecotourism, this is in accordance with the results of research Astuti \& Widodo (2018) that the results of identification of potencial and consumer interest in ecotourism are influenced by the diversity of mangrove species in the area Mangrove Bandar bakau, the increasing number of guests from year to year continues to arrive due to the interest in a product offered by Bandar mangrove ecotourism.

On the other hand, mangrove ecotourism has the potential for fauna, mangrove areas Mangrove Bandar bakau has several types of animals and biota including birds, fish, reptiles, mammals, insects, molluscs and crustaceans. Mangrove ecosystem around the mangrove forest area Bandar bakau Mangrove Dumai is unique, apart from the many types of mangroves, the condition of the ecosystem is very interesting. This uniqueness can be used as a tourist attraction for ecotourism activities. The carrying capacity of the ecotourism activity also needs to be analyzed to assess the tolerable capacity of visitors, so that the ecosystem can still be maintained in the area.

Meanwhile, the cultural potential of the ecotourism community Mangrove Bandar Bakau is tourism about history and tourism about religion, historical tourism pesanggrahan putri tujuh and religious tours to the pilgrimage of the tombs siti laut and hoch liong kiong pagoda. This tour is less attractive to tourists because of the distance and lack of access.

\section{Amenity Ecotourism Bandar Bakau Mangrove Dumai}

Amenities are facilities and infrastructure as well as accommodation that must be owned by every tourist spot manager, because this factor is an added power in any increase in tourism capacity, the results of the study explain that the identification of facilities is quite lacking.

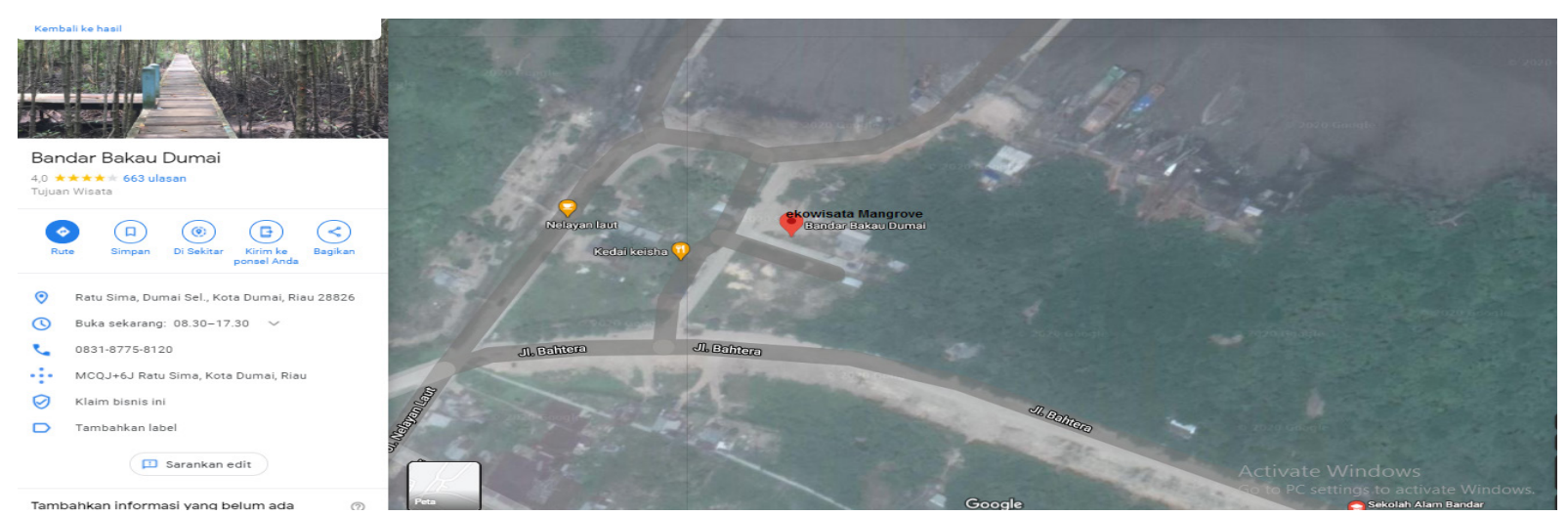

Figure 1: Map of Bandar Mangrove Mangrove Ecotourism 
Table 2. The Potential of Ecotourism in Bandar Bakau

\begin{tabular}{lll}
\hline No. & \multicolumn{1}{c}{ Amenities } & \multicolumn{1}{c}{ Information } \\
\hline 1 & The bridge to the beach & Available \\
2 & Multipurpose building & Available \\
3 & Ecotourism Center & Available \\
4 & Toilet & Available \\
5 & Islamic Prayer Room & Available \\
6 & Nature school & Available \\
7 & Traditional Malay House & Available \\
8 & Library & Available \\
9 & Parking lot & Available \\
10 & information Center & Available \\
11 & Health Place & Not available \\
12 & Food Court & Not available \\
13 & Public transport & Not available \\
14 & Trash can & Not available \\
15 & Mangrove Bank & Available \\
\hline
\end{tabular}

Source: Processed by researchers 2020

From the table above, it shows that the facilities in Bandar mangrove ecotourism are classified as very lacking, so it requires a development strategy that is right on target and utilizes local wisdom and the participation of the surrounding community to build supporting facilities. The tourism office of Dumai City has been willing to provide assistance for the development of mangrove ecotourism in Bandar mangrove with pre-determined categories. According to Mufid (2019) facilities are an important part of ecotourism development, ecotourism orientation must be based on environmental interests and provide benefits to tourists who come, these facilities must come from a need while maintaining the principles of nature.

\section{Accessibility for Mangrove Ecotourism Mangrove Bandar Bakau}

Accessibility is the most important thing in tourism activities. All kinds of transportation or transportation services are important access in tourism. On the other hand, this access is identified with transferability, which is the ease of moving from one area to another. If an area does not have good accessibility, such as airports, ports and roads, there will be no tourists who will affect the development of accessibility in that area. If an area has tourism potential, it must be provided with adequate accessibility so that the area can be visited.

Accessibility that is owned by Bandar mangrove ecotourism is defined as access to the Bandar mangrove area, accessibility includes all types of transportation both land, sea and air, since the inauguration of the Pekanbaru-Dumai toll road in September 2020, the number of people who come to the city of Dumai has increased so that transportation access by land can be reached with a distance of 1 hour, while road access is still not good.
Ancilliary Ecotourism Mangrove Bandar Mangrove

Supporting facilities tourism activities. ancillary service is more about the availability of public facilities and facilities used by tourists which also support the implementation of tourism activities such as banks, ATMs, telecommunications, hospitals and so on. Meanwhile explained that ancillary service includes the existence of various organizations to facilitate and encourage tourism development and marketing of the destination concerned. This is in line with Nguyen et al. (2020) that supporting tourism activities starts from mapping the potential for mangroves, early identification of the mapping will determine the direction of mangrove development so that a clear classification is needed for each mapping.

The supporting facilities for Bandar mangrove ecotourism are quite sufficient because this tourist spot is close to the urban center, lodging, telecommunications and other supporting facilities are sufficient, but access in ecotourism is lacking, this is what needs to be improved by the Bandar mangrove ecotourism manager.

\section{Internal and External Factors Strategy for Eco- tourism Development Bandar Bakau Mangrove}

Table 3. SWOT Analysis of Internal and External Factors Strategy

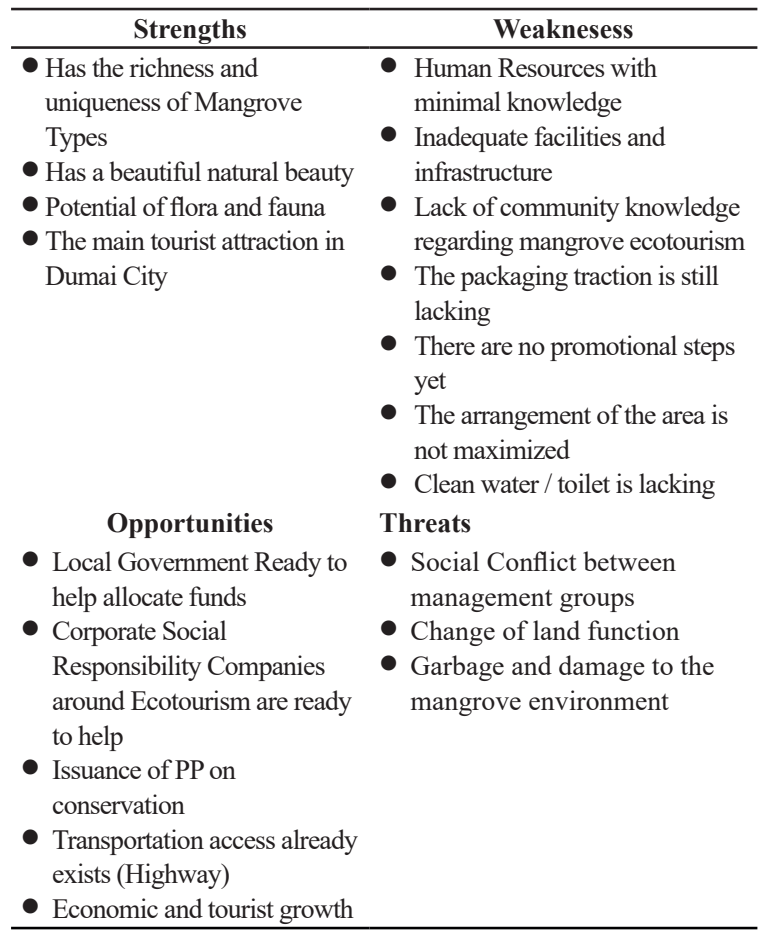

Local Wisdom-Based Mangrove Ecotourism Development Strategy in Bandar Bakau Mangrove

Based on an analysis that considers the importance of external and internal factors as well. The linkages between the factors (SWOT analysis) resulted in 4 alternative strategies for mangrove ecotourism activities Mangrove Dumai City is as 
follows: Based on an analysis that considers the importance of external and internal factors as well as the relationship between these factors (SWOT analysis), there are 4 alternative strategies for mangrove ecotourism based on local wisdom in mangrove cities as follows:

\section{Mangrove Conservation Development as a tourism program}

The negative impact of tourism is environmental damage. Although the concept of ecotourism always prioritizes conservation in it, it cannot be denied that violations against it are still frequently encountered. This is not only due to the lack of knowledge and awareness of the surrounding community about the concept of ecotourism, but opportunities for destruction also exist if there is no sanction or strict supervision from the management and the government. As written in the research Sidiq (2007) that the well-preserved mangrove ecosystem has tourism potential that can be developed. it will be achieved when it is planned properly and according to the carrying capacity of the environment. This strategy will be achieved considering that in ecotourism activities there is the potential for local wisdom of the Malay community around Bandar Mangrove which seeks to maintain the authenticity of the biological and physical components in the mangrove ecosystem which is the main attraction of ecotourism activities in the mangrove ecosystem.

The development of conservation efforts in the Bandar mangrove ecotourism area can be carried out by the local government and managers can also be coordinated with Nature Lovers activity units or student organizations from various universities in Dumai City and Riau Province. This can be done through various activities that are environmentally friendly in a sustainable manner. Such as monitoring after planting mangroves, maintaining cleanliness and guiding the tourists who come. This strategy is the same as that proposed by Karlina (2015) In his research in the Kalimantan region that encouraging community participation in ecotourism development must be based on mutual desire. Increased conservation efforts in the region Bandar Bakau Mangrove Besides being able to be carried out by the local government, it can also be coordinated with non-governmental organization units. As can be done by continuing to carry out activities that are friendly to the environment, such as maintaining nature reserves and cleanliness as well as supervising or guiding tourists who come and carrying out updated data collection.

\section{Increase participation and empowerment of tourism communities.}

One of the concepts of ecotourism development is to increase community participation in management, so that it can be beneficial for the local economy. The existence of existing community empowerment programs should be further developed and more activated. In addition, community participation needs to be further developed to become tour guides. This is to bridge the desires of tourists and the concept of ecotourism development. According to Hayati (2010) The local community is actually not an obstacle to the development of Ecotourism, because their role should not be separated in tourism programs. This community-based management is one of the natural management approaches that place the knowledge and environmental awareness of the local community as the basis for its management.

Meanwhile, according to Kaharuddin, et al (2020) The participation and empowerment of the tourism community is divided into 3 kinds of levels, the pioneering level, the community determines the direction of joint policies based on their values and norms, in fact the local government only facilitates while the management is left to the surrounding community for increasing welfare, the community development level begins to develop with the direction of government, related stakeholders and academics who always accompany the ecotourism development process and the last level of development is that it has developed and the community just needs to maintain and improve from any deficiencies both in terms of facilities and organization, these all become benchmarks for ecotourism development strategies in Bandar Bakau Mangrove Dumai City.

\section{Coordination and Issuance of Regional Regulations}

Mangrove ecosystems have a very important function for coastal areas. Mangrove forests have various physical, ecological, economic and sociocultural functions. Physical functions include stabilizing coastal areas, protecting coastlines, and maintaining sediment stability. Ecological functions are the spawning ground, nursery ground and feeding ground for the fauna associated with it. The economic function of the mangrove ecosystem is as a livelihood for the surrounding community; while the socio-cultural function of mangrove forest is to enable it as a tourist destination and as an area for cultural development, conservation and education.

Ecotourism Bandar mangroves in Dumai City Do not have binding rules for local regulations in mangrove conservation, this is a challenge in the future that the government as the leading sector must prepare rules to anticipate natural damage and the sustainability of mangrove nature in Dumai City. 
As well as building coordination between local, provincial and central governments in the development of Bandar mangrove ecotourism, weak coordination makes mangrove ecotourism in Bandar mangrove rarely in demand, in the future all parties work together to build cooperation. This is in accordance with the opinion Hermawan \& Setiawan (2018) which states that the output is coordinating rules or laws regarding protection or conservation in mangrove areas mangrove town.

\section{Strengthening the concept of ecotourism based on local wisdom}

Mangrove ecotourism area Mangrove Bandar Bakau has the potential for attractive natural tourism which needs to be further developed by the government. This can have an impact on improving the community's economy. The appropriate ecotourism concept will minimize the negative impact on environmental damage. Because the concept of ecotourism is oriented towards a balance between tourism and the interests of protecting natural resources / environmental conservation by using resources and involving local communities. According to (Wardhani, 2011) Ecotourism activities directly have the benefit of preserving nature and the environment as well as improving the social and economic conditions of the surrounding community. In addition, this ecotourism activity also provides environmental information which is expected to increase public knowledge and awareness in loving nature. While the development strategy according to (Aryunda, 2011) in his research on mangrove ecotourism in the Thousand Islands that improving mangrove ecosystem management efforts through alternative ecotourism activities to utilize mangrove forests is the most possible without damaging the mangrove ecosystem, including: scientific research, scientific research, education, and limited recreation / ecotourism.

\section{Improving the quality of human resources managing the Bandar Mangrove Ecotourism activity}

The results showed that the level of education and ability of mangrove ecotourism managers Mangrove Bandar Bakau no one has expertise in developing tourist attractions, so far the manager has also not received any training from related institutions, the surrounding community only relies on internet access in ecotourism management Bandar Bakau Mangrove Therefore, in terms of ecotourism development strategies, it is necessary to improve the quality of human resources for management, they will be provided with some training and education regarding ecotourism development activities, this is in line (Karlina, 2015) that training and education will provide positive impact on the area or area, but also provides added value to visitor satisfaction, the ability of managers to be able to compete in the world eco-tourism market and all forms of ecotourism activities in accordance with the norms of the use of sustainable forest environmental services in conservation efforts. area.

\section{Promotion of Ecotourism through websites and social media platforms.}

So far, the management of the Bandar mangrove tourism area does not have an official account to help with marketing on social media, while the development of social media platforms and websites is very promising to be an added power. In the future, Bandar Bakau ecotourism promotion strategy must use social media, according to (Adhanisa \& Fatchiya, 2017) Promotion can be categorized as important for tourism activities to take place. Promotion is a type of communication that provides convincing explanations for potential buyers about goods and services. This makes promotion an introduction tool that will convince, remind, and attract the attention of potential customers. There are two types of media that can be used as a means of promotion, namely conventional media which includes booklets, leaflets, posters and brochures. Meanwhile, online media take advantage of the internet network. Each social media certainly has different characteristics with their respective strengths and weaknesses.

Nafila (2013) mentioned there are three basic points of promoting ecotourism through social media and creativity. First, creativity is very important in the way of life and work now and forever. Second, human creativity is very diverse and multidimensional and is not limited to technological innovations and new business models. Third, the current issue is the constant pressure between organization and creativity.

\section{CONCLUSION}

The results of the SWOT analysis provide strategic steps for developing ecotourism based on local wisdom in the Bandar Bakau area, Dumai City, first developing mangrove conservation and rehabilitation as a form of new tourism potential in Bandar mangrove ecotourism, secondly increasing participation and empowerment based on local wisdom of the surrounding community, third formulating regulations and policies to preserve 
mangroves based on local wisdom of the Malay community, four strengthening the ecotourism concept in Bandar mangroves which aims to increase economic value and environmental sustainability value, fifth increase ecotourism management human resources and finally utilize social media platforms and the internet as an ecotourism promotion.

\section{REFERENCES}

Adhanisa, C., \& Fatchiya, A. (2017). Efektivitas Website Dan Instagram Sebagai Sarana Promosi Kawasan Wisata Berbasis Masyarakat. Jurnal Sains Komunikasi Dan Pengembangan Masyarakat, 1, (4), 451-466.

Adyla,N.,\&Nurlaela.(2018). StrategiPengembangan Desa Wisata Berbasis Kearifan Lokal Di Desa Tammangalle Polewali Mandar. Jurnal Plano Madani, 7, (2), 132-141.

Aryunda, H. (2011). Dampak Ekonomi Pengembangan Kawasan Ekowisata Kepulauan Seribu. Journal of Regional and City Planning, 22, (1), 1. https://doi. org/10.5614/jpwk.2011.22.1.1

Astuti, D., Widodo, T., \& Bengkalis, P. N. (2018). Identifikasi potensi serta minat konsumen akan ekowisata mangrove di pulau Bengkalis. Jurnal Inovasi Dan Bisnis (INOBIZ), 6, 135141.

Dahuri.R. (2003). Keanekaragaman hayati laut: aset pembangunan berkelanjutan Indonesia. Gramedia Indonesia.

Edi, M., Okik Hendriyanto, C., \& Nur, F. (2009). Konservasi Hutan Mangrove Sebagai Ekowisata. Envirotek: Jurnal Ilmiah Teknik Lingkungan, 1, 51-57.

Edy Saputra, S., \& Setiawan, A. (2014). Potensi Ekowisata Hutan Mangrove Di Desa Merak Belantung Kecamatan Kalianda Kabupaten Lampung Selatan. Jurnal Sylva Lestari, 2, (2), 49. https://doi.org/10.23960/js12249-60

Efendi, N. (2014). Model Kelembagaan Perizinan Bagi Industri Tekstil Di Kabupaten Bandung. Sosiohumaniora, 16, (June), 1-2.

Fitriana, D., Johan, Y., Studi, P., Kelautan, I., Pertanian, F., Bengkulu, U., \& Belakang, L. (2016). Analisis Kesesuaian Ekowisata Mangrove. Jurnal Enggano, 1, (2), 64-73.

Ghazali, I., Setyobudiandi, I., Kinseng, R. A., Bogor, P., Raya, J., Kampus, D., \& Darmaga, I. P.
B. (2014). Pengelolaan mangrove berbasis masyarakat di Pantai Timur Surabaya Community base of mangrove management in Surabaya East Coast. Depik, 3, (3), 195206.

Hayati, S. (2010). Partisipasi Masyarakat dalam Pengembangan Ekowisata di PangandaranJawa Barat. Forum Geografi, 24, (1), 12. https://doi.org/10.23917/forgeo.v24i1.5012

Klein, M. L., Humphrey, S. R., \& Percival, H. F. (1995). Effects of ecotourism on distribution of waterbirds in a wildlife refuge. Conservation biology, 9, (6), 1454-1465.

Hermawan, A., \& Setiawan, H. (2018). Kearifan Lokal Masyarakat Pulau Tanakeke dalam Mengelola Ekosistem Mangrove. Balai Litbang Lingkungan Hidup Dan Kehutanan Makassar, 15 .(1), 53-64. Retrieved from

Rahadian, A. S. W. I. N. (2019). Model Spasial Pendugaan Biomassa dan Karbon Mangrove di Indonesia (Doctoral dissertation, thesis]. Bogor: Sekolah Pasca Sarjana-IPB University).

Rangkuti, F. 2005. Analisis SWOT: Teknik Membedah Kasus Bisnis-Reorientasi Konsep Perencanaan Strategis untuk Menghadapi Abad 21. Cetakan ke-10. Jakarta: Gramedia Pustaka Utama

Kaharuddin, K., Pudyatmoko, S., Fandeli, C., \& Martani, W. (2020). Partisipasi Masyarakat Lokal dalam Pengembangan Ekowisata. Jurnal Ilmu Kehutanan, 14, (1), 42. https:// doi.org/10.22146/jik.57462

Karlina,E. (2015). Strategi PengembanganEkowisata Mangrove Di Kawasan Pantai Tanjung Bara, Kutai Timur , Kalimatan Timur. Jurnal Penelitian Hutan Dan Konservasi Alam, 12, (2), 191-208. https://doi.org/10.20886/ jphka.2015.12.2.191-208

Kurniasari, N., \& Reswati, E. (2011). Kearifan Lokal Masyarakat Lamalera: Sebuah Ekspresi Hubungan Manusia Dengan Laut. Buletin Ilmiah Marina Sosial Ekonomi Kelautan Dan Perikanan, 6, (2), 29. https://doi.org/10.15578/ marina.v6i2.5810

Mastika, I. K. (2018). Pengembangan Ekowisata Berwawasan Kearifan Lokal Di Wilayah Eks Karesidenan Besuki, Jawa Timur. Jurnal Master Pariwisata, 4, 240-252. https://doi. org/10.24843/JUMPA.2018.v04.i02.p06 
Mufid, M. (2019). Fikih Ekowisata Berbasis Maqāșid Al-Syarı̄'ah: Studi Pengelolaan Wisata Alam Hutan Mangrove Di Wonorejo Kota Surabaya Moh. Al-Manahij: Jurnal Kajian Hukum Islam, 8, (5), 55.

Nafila, O. (2013). Peran Komunitas Kreatif dalam Pengembangan Pariwisata Budaya di Situs Megalitikum Gunung Padang. Journal of Regional and City Planning, 24, (1), 65. https://doi.org/10.5614/jpwk.2013.24.1.5

Nazir, M. (2005). Metodologi Penelitian (Research Methodology). Bogor: Ghalia Indonesia.

Nguyen, H. H., Nghia, N. H., Nguyen, H. T. T., Le, A. T., Tran, L. T. N., Duong, L. V. K., ... Furniss, M. J. (2020). Classification methods for mapping mangrove extents and drivers of change in Thanh Hoa province, Vietnam during 2005-2018. Forest and Society, 4, (1), 225-242. https://doi.org/10.24259/ fs.v4i1.9295

Sari, Y., Budi Yuwono, S., \& . R. (2015). Analisis Potensi Dan Daya Dukung Sepanjang Jalur Ekowisata Hutan Mangrove Di Pantai Sari Ringgung, Kabupaten Pesawaran, Lampung. Jurnal Sylva Lestari, 3, (3), 31. https://doi. org/10.23960/js13331-40

Sawitri, R., Bismark, M., \& Karlina, E. (2013). Ekosistem Mangrove Sebagai Obyek Wisata Alam Di Kawasan Konservasi Mangrove Dan Bekantan Di Kota Tarakan (Ecosystem Mangrove as an Ecotourism in Conservation Area for Mangrove and Proboscis Monkey at Tarakan City). Jurnal Penelitian Hutan Dan Konservasi Alam, 10, (3), 297-314.
Sidiq, Siti Sofro, Sulistyani.A, M. (2007). Strategi Promosi Ekowisata Mangrove. Jurnal Aplikasi Bisnis, 8, (1), 91-96.

Susanto, E. al. (2016). Potensi Dan Daya Dukung Kawasan Ekowisata Hutan Mangrove Bandar Bakau Dumai. Jurnal Online Mahasiswa, 3, (2), 99-102. https://doi.org/10.13581/j.cnki. rdm.20161021.001

Thamrin, H. (2013). Kearifan Lokal dalam Pelestarian Lingkungan ( The Lokal Wisdom in Environmental Sustainable ). Kutubkhanah, 16, (1), 46-59.

Vuspitasari, B. K., \& Ewid, A. E. (2020). Peran Kearifan Lokal Kuma Dalam Mendukung Ekonomi Keluarga Perempuan Dayak Banyadu. Sosiohumaniora, 22, (1), 26-35. https://doi.org/10.24198/sosiohumaniora. v22i1.24078

Wahyuni. Sri, D. (2015). Strategi Pengembangan Ekowisata Mangrove Wonorejo Kecamatan Rungkut Surabaya. Diponegoro Journal of Maquares, 4, (4), 1-14. Retrieved from http:// ejournal-s1.undip.ac.id/index.php/accounting

Wardhani, M. K. (2011). Kawasan Konservasi Mangrove: Suatu Potensi Ekowisata Maulinna Kusumo Wardhani. Jurnal KELAUTAN, 4, (1), 60-79.

Zamzami, L. (2016). Dinamika Pranata Sosial Terhadap Kearifan Lokal Masyarakat Nelayan Dalam Melestarikan Budaya Wisata Bahari. Jurnal Antropologi: Isu-Isu Sosial Budaya, 18, (1), 57. https://doi.org/10.25077/ jantro.v18i1.53 